\title{
The students' image of geography: A systematic review
}

\author{
VERONIKA KORVASOVÁ
}

Masaryk University, Faculty of Education, Department of Geography, Brno, Czechia; e-mail: vkorvasova@mail.muni.cz

ABSTRACT Geography as a school subject is facing a crisis of identity. Student interest in geography has decreased and the lack of solutions for improving geography's image opened a research gap. The aim of the paper is to summarize the knowledge and understanding from the pupils' perspective and prepare the ground for conducting similar research in Czechia. Getting the pupils' perspective is crucial for shaping the subject in a more favorable direction and in defending geography's place in the education system. Subsequently it creates concrete arguments for defending and stabilizing. The author searched for studies using the WoS and Scopus databases. Three criteria were set: studies only in English, the maximum time limit as February 2020, and the age of researched students as 11-19 years. Twenty-seven relevant studies, mainly conducted in English speaking countries, were found. The review focuses especially on applied methods and results of studies. Results showed that quantitative methods prevailed over qualitative. Factors such as the personality of the teacher, teaching methods, and geography topics seemed the most important in the process of developing a positive image of geography.

KEY WORDS image - geography - student - pupil - geography education

KoRvASOvÁ, v. (2021): The students' image of geography: A systematic review. Geografie, 126, 4, 347-370.

https://doi.org/10.37040/geografie2021126040347

Received August 2021, accepted November 2021.

(C) Česká geografická společnost, z. s., 2021 


\section{Introduction}

Geography has a unique place among scientific disciplines and school subjects, as it brings together knowledge about the environment, space, and time. In most countries, geography is a traditional part of the curriculum, either as a separate school subject, or integrated within the natural and social sciences. Yet worldwide, the subject of geography has been facing threats in the form of attempts to reduce or even abolish geography teaching, which raises questions about geography's position in education systems (van der Schee 2014; Béneker, Palings, Krause 2015). There has been a global decrease in learning hours per subject for geography, which makes students less interested in studying geography at higher school levels (Adey, Biddulph 2001; Kitchen 2013; Jan Bent, Bakx, den Brok 2013). The interest in studying geography at universities is also gradually declining (Gibson 2007, Kidman 2018). This is likely why many publications today discuss the usefulness of geography in everyday life (Murphy 2018; Parkinson 2020).

However, we cannot measure the interest in geography and its popularity only by measuring the learning hours per subject or the number of applicants for geography programs at universities. These measures are themselves a consequence of how students perceive geography on a long-term basis. This study expands the current state of knowledge by summarizing the existing research that examines how students perceive geography, paying special attention to the factors that affect the image of geography. This study presents a systematic literature review of 27 earlier studies. The aim is, first, to define the image of geography, and then to answer the following research questions: What research methods did researchers use to study the image of geography? What research findings did the researchers report? What factors affect students' perceived image of geography? This review serves as an introductory article on the topic of the image of geography, and its main goal is to lay foundation for future research in this area.

In the first part of the review, I define the concept of the image of geography and describe the criteria for selecting the studies that examined the image of geography from the students' perspective. After this, I describe the goals and methods that were used. I then summarize the research findings regarding the image of geography from the students' perspective, as well as the factors that affect this image. In conclusion, I formulate recommendations for further research to help determine the students' perception of school geography and take measures that would inspire more students to study geography. 


\section{What is the image of geography and why should we study it?}

The term "image of geography" first appeared in the 1980s (Dawson, Hebden 1984). The image of geography as a theoretical concept is not a frequent subject of empirical research. One work that does examine this concept is a unique work by Miener (2016), published in German. The image of geography is often mentioned in connection with the crisis of the identity of geography as a scientific field or as a school subject (Rallis, Rallis 1995). The term "image" refers to the image, form, or idea of a given thing, specifically to its external influence and the overall impression it makes on an individual or the public.

To explain how the image works in society and what influence it has, I use the theory of the social construction of reality (Berger, Luckmann 1999), which states that the world is influenced by social interactions and is created by society. Therefore, the image functions as an objective reality, which, at the same time, shapes people. This means that we are constantly moving in a circle that is affected by our thoughts and actions. We are continuously reshaping the image that in turn shapes our thoughts.

I define the image of geography using a synthesis of three field-specific definitions of the image: psychological, sociological, and economic. First, the individual creates the image. Therefore, I proceed from a psychological point of view (Colman 2015 , np.), defining the image "as a depiction or likeness of an object. A mental representation of a stimulus in the absence of the physical stimulus, formed by the imagination or memory (also called mental image). The appearance of a character that a person or an organization presents in public." An image is first formed by individuals, who, on the basis of their inner beliefs, form an opinion about things and perceive them in a certain way. However, it is important to note that all individuals enter a reality with a limited awareness of the matter, and then adjust their opinion based on their experience. In the case of geography, all individuals reach their own idea of the image of geography. All related processes take place within each individual separately, and only when the individual has formed an opinion of the image of geography does he/she present it externally. This means that social reality is constantly transformed according to how it is perceived by individuals and society. From now on, we can talk about externalization and the creation of an image that already reflects the opinion of a large group or of society as a whole.

At this point, it is necessary to reflect on the sociological context, which helps us understand the behavior of the individual in society. From the sociological point of view, an image or imaginary construct is perceived as a certain idea (mental representation) that is externalized within society and is based on our experience and reflection. The sociological imagination has been defined by C. Wright Mills as the vivid awareness of the relationship between personal experience and the 
wider society (Mills 2000). This concept can be adapted for our purposes. The value and position of geography among other subjects and disciplines are defined by how it is understood in society. To appreciate the value of geography, society must understand its purpose.

To influence and improve the image, it is necessary to move into the economic sphere, which has worked with the image traditionally. The image must be improved on a continuous basis. If we do not build it systematically, it gradually becomes more negative; therefore, it takes work to maintain it at the same value level or to improve it. If we want to improve the image, we must approach it as entrepreneurs. In economics, the image is an "illusory conception created by advertising and projected by the media, that embodies emotions, perceptions, attitudes, and intellectual orientation group toward an entity" (Imber, Toffer 2000, p. 281). We can work with the image of geography in a targeted way, either to propose recommendations and measures for the future or to undertake targeted promotion of geography in the field of education policy.

To summarize, in this study, I define the image of geography as a comprehensive set of attitudes, ideas, and expectations about geography, based on how geography is presented externally. In the context of education, the image of geography can be explored on the basis of sensory qualities without rational assessment, without proper argumentation, or on the basis of the perception of others. The better the understanding of the subject, the better its image, and the higher the value of geography and geographers in society.

Based on this definition, I have identified the constructs that can form the dimensions of the image of geography. The first such construct is the attitude, which is defined as a relatively permanent characteristic of an individual's personality and represents an evaluation, preference, or rejection based on the available information. It consists of three key components: the cognitive component, expressing the level of acquired knowledge about the attitude object; the emotional (affective) component, considering predictive feelings, emotions, and emotionally colored reactions to the attitude object; and the conative (behavioral) component, representing the tendency to behave or act in a certain way with respect to the attitude object (Eagly, Chaiken 1993).

The second construct is the students' perception. The process of perception can be described as the acceptance of its simplest isolated elements, i.e., sensations. It is a process through which the individual obtains information about the surrounding objects, qualities, and relationships through the senses. Physiological, psychological, and social factors are all involved in the process (Adey, Biddulph 2001).

Another research construct is the conception of geography as a subject. Conception is an idea or a particular way of understanding or thinking about something, or a basic understanding of a situation or principle (Walter 2008). 
In addition, the image can also be created with the help of students' beliefs, motivation, and interest in the subject. It is important to mention that none of these concepts are defined in the literature in a consistent way. However, the following definitions are sufficient for the purposes of this article. According to Colman, belief is "any proposition that is accepted as true on the basis of inconclusive evidence. A belief is stronger than baseless opinion but not as strong as an item of knowledge. More generally, belief is conviction, faith, or confidence in something or someone" (2015, np.). Motivation is "a driving force or forces responsible for the initiation, persistence, direction, and vigour of goal-directed behaviour" (Colman 2015, np.). Interest can be defined as "a certain intrinsic motivation, which has some essential aspect” (Schiefele 1991, p. 302). Also, examining beliefs as an attitude is not ideal. However, despite the limitations of the research constructs, we can use them to measure the image; therefore, they were chosen as keywords when searching for suitable publications for the review study.

\section{Methodology}

A systematic review study approach was used (Petticrew, Roberts 2008; Snyder 2019). Content analysis was carried out on selected studies (Neuendorf 2016). The research studies were found through the professional databases, because the texts of the papers included there are peer-reviewed and expected to meet certain quality standards.

\subsection{Search in databases}

I searched mainly in the Scopus and the Web of Science databases. Then I added eligible articles through Google Scholar when I could not find the full version of articles in the databases. I searched for articles using a combination of keywords: geography, student, pupil, image, attitude, perception, conception, belief, motivation, interest. I entered the search command in Scopus in the following form: geography AND (student OR pupil) AND (image OR perception OR conception OR attitude OR motivation OR belief OR interest). I entered a similar combination of words in the Web of Science. Originally, I wanted to search for articles using only a combination of geography, student, pupil, and image; however, I found that this combination is not used in connection with geography, so I chose other keywords that, in my opinion, fall under the concept of image. Scopus yielded 78 publications, and Web of Science, 46 publications. 


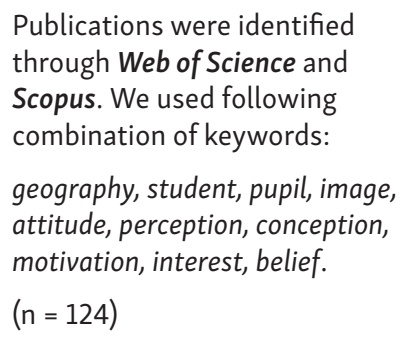

Publications were identified through Web of Science and Scopus. We used following combination of keywords:

geography, student, pupil, image, attitude, perception, conception, motivation, interest, belief.

$(n=124)$

Duplicate publications removed.

$(n=35)$

\section{Publications after duplications} were removed.

$(n=89)$

Publications discarded after reading title and abstract.

$(n=43)$

Publications that, according to the abstract, seemed relevant and were read closely.

$(n=46)$

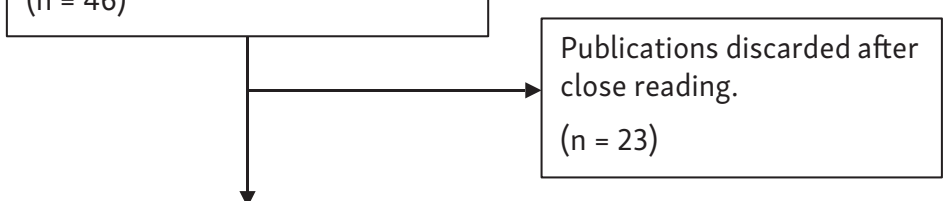

Publications that matched the defined criteria, were included in the study, and were analyzed. $(n=20)$

Snowball sampling. Publications found through references. $(n=7)$

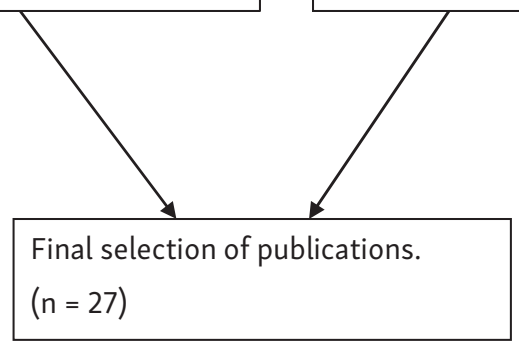

Fig. 1 - Visual description of the publication selection process (my own illustration). 


\subsection{Criteria}

Initially, I did not set any time limit while searching for publications. The oldest identified source was from 1979, and the most recent was a publication from February 2020, when this date was additionally set as the upper time limit. I searched for studies only in English. The last criterion was that the studies must focus only on students attending secondary school (ages 11-19). I was looking for studies published in journals, but I also deliberately included a monograph by Nick Hopwood (2014), as it was entirely devoted to my topic.

\subsection{Elimination Process}

At the first stage, I looked at the titles of the articles and eliminated ones that did not match my focus. At the second stage, I read the abstracts of the remaining articles, from which I selected only those relevant to my topic. If I could not find the whole-text version of an article in the database, I searched for it in Google Scholar. Since I had found only 20 relevant articles at the end of the database search, I then used them to perform the following snowball sampling. For all selected publications, I went through the references in search of other suitable publications that were not included in the databases. The whole process of elimination is described in the Figure 1. The selected publications are listed in Table 1.

\section{Findings}

This chapter is organized into subchapters to present the answers to the three main questions formulated in the introduction. I tried to answer them through content analysis conducted on the studies. The first subchapter deals with the methods used to research the image of geography. The following chapter presents an overview of the image of geography in the studies analyzed, and the third lists the selected factors that affect the image of geography.

\subsection{Research methods}

When investigating the image of geography, both quantitative (15 studies) and qualitative methods ( 7 studies) were used; in 5 cases, the research had a mixed design and used both. In about two-thirds of the surveys, various types of questionnaire surveys were used; i.e., quantitative data collection predominated. 


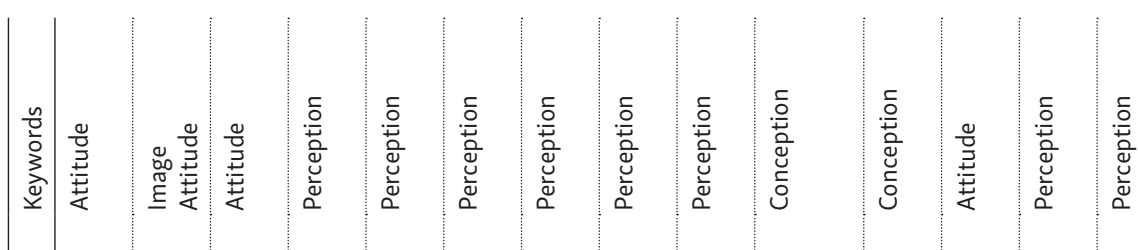

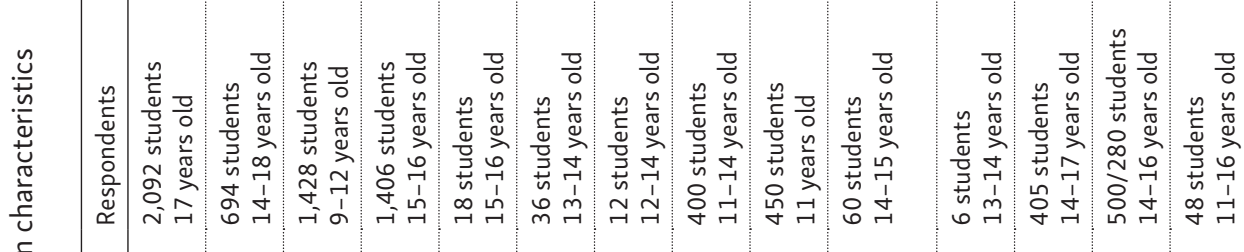

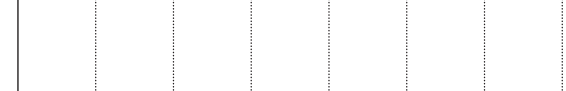

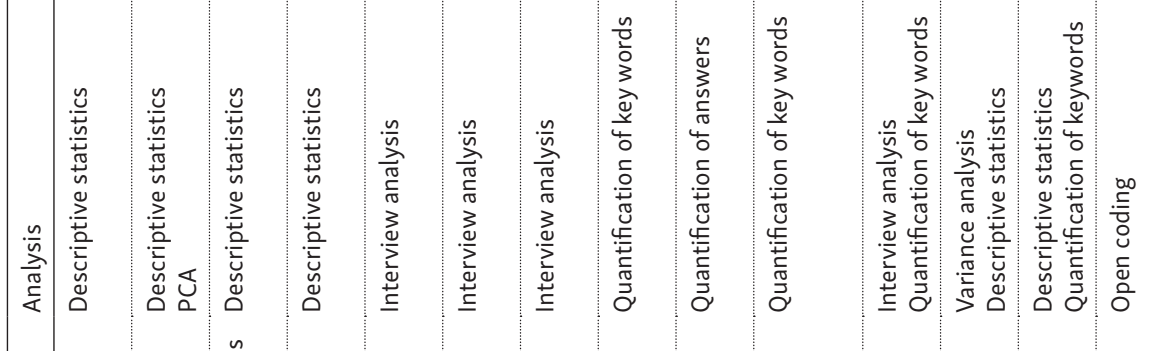

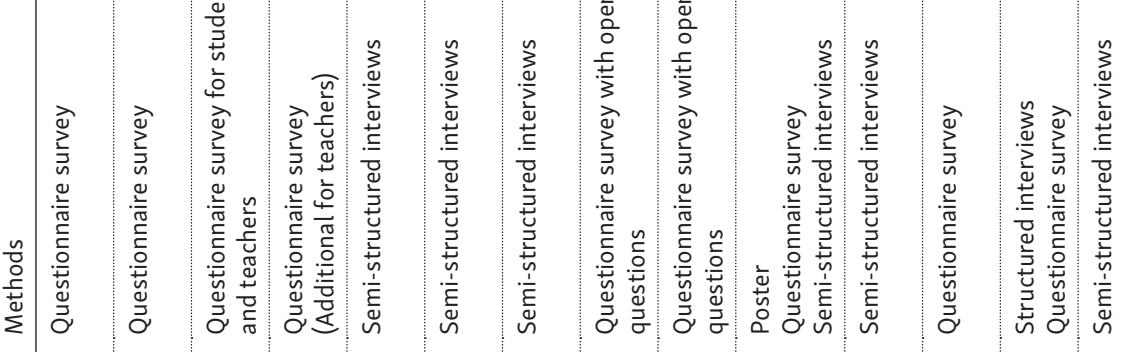

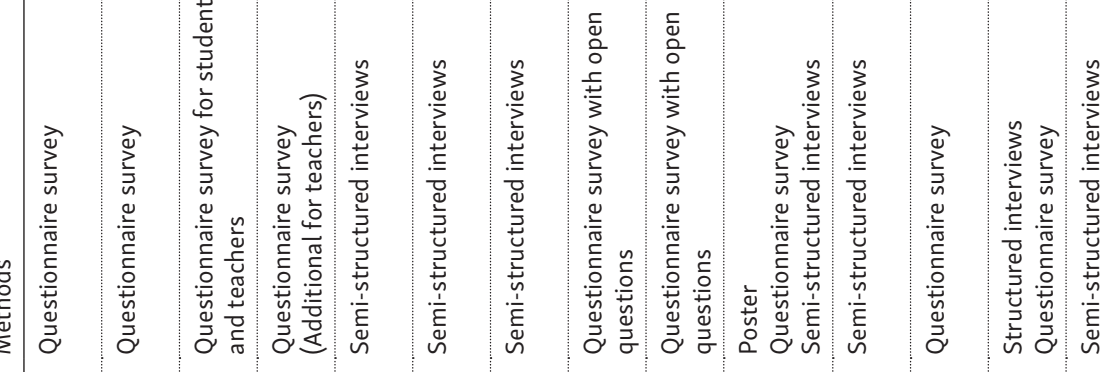

n 0 na v 


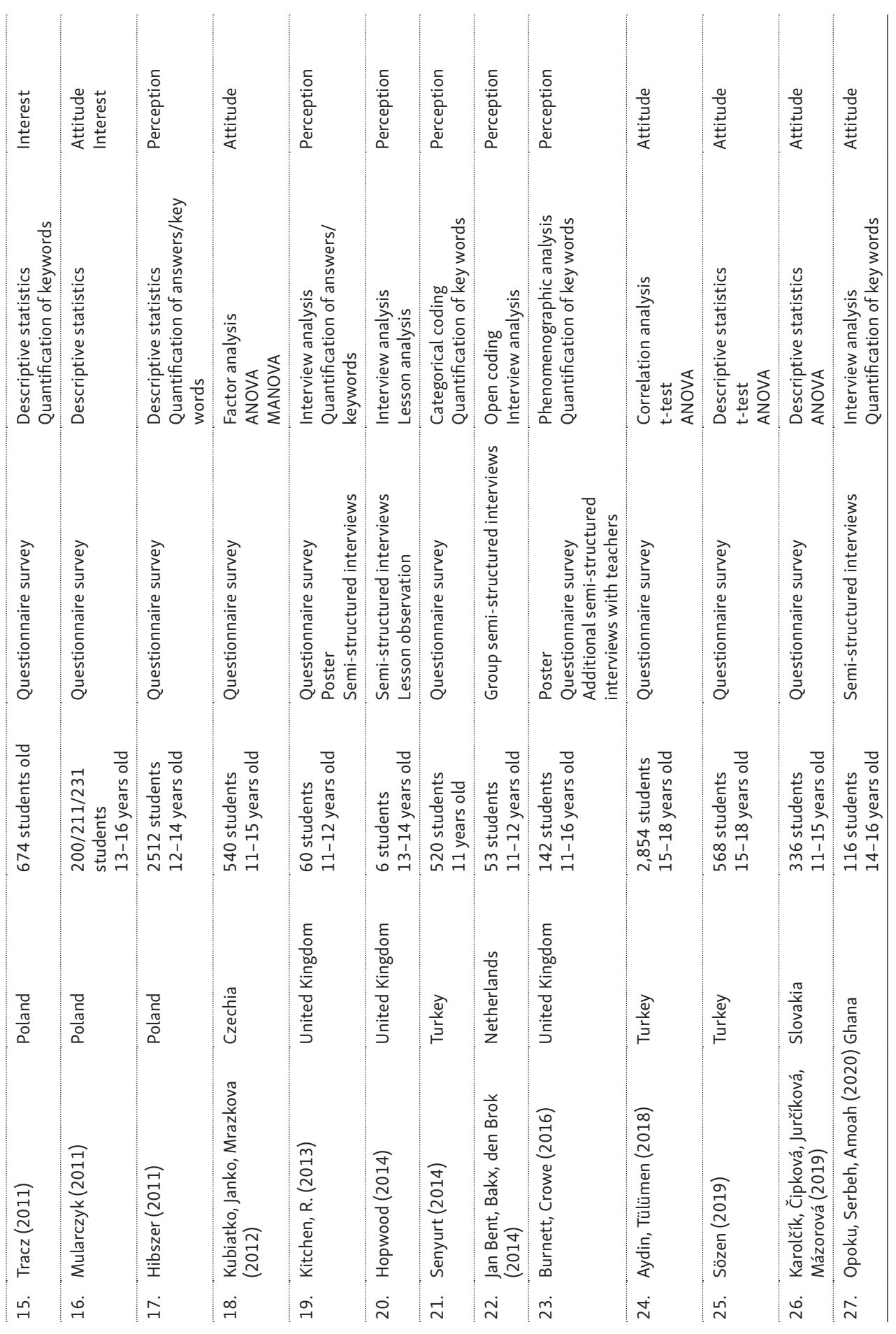




\subsubsection{Quantitative methods}

Most of the quantitative studies investigated the image of geography through questionnaire surveys. The first set of papers compared the popularity of geography to that of 5 or 6 other subjects. Students sorted the subjects in descending order of popularity, and their answers were summarized and averaged (McTeer 1979; Sack, Petersen 1998). Thanks to the simplicity of the research tool, it is possible to work with data obtained from a large sample of students. In the case of the McTeer research (1979), 2,029 students participated in the research, and in the case of Sack and Petersen (1998), 1,428 students. Hibszer (2011) also used the ranking of subjects according to popularity in a part of the questionnaire survey; students chose their favorite subject in general, and then their favorite subject among the natural sciences.

The second group of quantitative studies investigated students' attitudes to geography. Students commented on statements concerning geography, rating them on a 4- or 5-point Likert scale (Hubbard, Stoddard 1979; Tomal 2010; Kubiatko, Janko, Mrazkova 2012; Aydin, Tülümen 2018; Sözen 2019; Karolč́́k et all 2019). The advantage of this kind of research is that the questions can be divided into several groups, which allows multiple dimensions of the image of geography to be considered. Hubbard and Stoddard (1979) asked 30 questions, with 10 questions dedicated to every one of three dimensions: knowledge, attitude to geography, and attitude to teaching. In Karolčík et all (2019), 18 questions were thematically divided into three groups, according to three dimensions of attitude: cognitive, affective, and conative. Kubiatko, Janko, and Mrazkova (2012) divided 27 questions into four dimensions: geography as a school subject; geography and the natural environment; the importance of geography; and the relevance of geography to everyday life. Aydin and Tülumen (2018) studied the relationship between anxiety and the attitude toward geography; students used scales to respond to statements divided into two groups related to either anxiety or attitude. Similarly, Sözen (2019) examined three dimensions: attitudes toward geography lessons, views on teaching activities, and views on the aids used. He asked 33 questions, which students answered using a scale. Mularczyk (2011) also worked with a scale, repeatedly giving Polish students a questionnaire with 17 closed questions. The questions were divided into five groups according to topics, and the students answered using scoring scales with between 2 and 18 points. This research was inspired by Tracz (2011), who combined questions answered on a scale in a questionnaire survey (14) with supplementary open-ended questions (6).

The third group is represented by open-ended surveys, where the authors most often asked what geography is. Students were asked to characterize geography using keywords, to describe what they found useful in geography, or to describe what they had learned through geography. They were also asked to list things 
they liked and did not like about geography. For open answers, evaluation was performed using content analysis; popular and unpopular aspects of geography were listed. This form of questionnaire survey was first used by Norman (2004) and Harrison and Norman (2004), who obtained and analyzed data from 400 and 450 students, respectively. This research was later incorporated into mixed design research by Burnett and Crowe (2016), where students were asked to write down a definition of geography in the second phase of the research. The same task was used in the study by Senyurt (2014), where students had to write, in addition to the definition of geography, topics that they associated with geography. Adey and Biddulph (2001) also chose a combination design with open-ended questions, but added a section where students answered only yes/no questions.

\subsubsection{Qualitative inquiry}

Semi-structured interviews were used as the main research tool in 8 studies, either with one student (Lam, Lai 2003; Hopwood 2009; Hopwood 2014; Opoku, Serbeh, Amoah 2020) or with a group (Biddulph, Adey 2003, 2004; Al-Nofli 2010; Jan Bent, Bakx, den Brok 2014).

Lam and Lai (2003) spoke individually with 12 students. Hopwood $(2009,2014)$ interviewed six students from three different schools; he conducted the interviews the end of the geography lesson over a period of three months, and spoke to each student at least 11 times. Individual interviews were also used by Opoku, Serbeh, and Amoah (2020), although the research sample consisted of 116 students. All interviews began with the following question: "Is geography one of your favorite school subjects, and why?" Depending on the answers, the authors then asked about the reasons and arguments supporting the students' opinions. All conversations were recorded, transcribed, and searched for keywords, which were used in the coding. Biddulph and Adey $(2003,2004)$ also chose group interviews with a maximum of six students per group over two consecutive years. Their structured interviews followed up on their earlier questionnaire survey from 2001, where they focused mainly on identifying retrospectively the concept of geography in Key Stage 3 according to students, as well as on what teaching methods made geography attractive for students. Group interviews were also used in a Dutch study (Jan Bent, Bakx, den Brok 2013), which obtained data from 53 students, who were divided into 12 groups. Al-Nofli (2010) also conducted interviews with 48 students. The individual answers were subjected to content analysis. Interviews were usually recorded, transcribed, encoded with keywords, and evaluated using software. According to the codes, categories and subcategories of terms used by the students were created. In the case of Jan Bent, Bakx, den Brok (2013), Hopwood $(2009,2014)$, and Opoku, Serbeh, Amoah (2020), an open qualitative analytical approach was taken. 


\subsubsection{Mixed design methods}

Mixed design was used by 5 studies (Hopwood, Courtley-Green, Chambers 2005; Bar-Gal, Sofer 2010; Kitchen 2013; Burnett, Crowe 2016). Hopwood, CourtleyGreen, and Chambers (2005) divided their research into three phases. In the first phase, they asked a group of 60 students to work in pairs to create a poster, presenting what geography meant to them. Subsequently, they looked for recurring motifs in the posters. The creation of the posters was then supplemented by a questionnaire survey, where students were asked to state their opinion on geography and explain what they learned in this subject and in what ways the subject was useful and interesting. In addition, they verified the resulting findings with additional semi-structured interviews with four randomly selected students. Kitchen (2013) also worked with a large group of 60 students (two classes). This study was based on research by Hopwood, Courtley-Green, and Chambers (2005), and the students also made posters. She then selected six students out of the research sample to write a definition of geography, which she used as a basis for additional semi-structured interviews. The evaluation was performed by content analysis. The research performed by Burnett and Crowe (2016) was identical, except that they did not conduct semi-structured interviews and included 142 students in the research. Bar-Gal and Sofer (2010) asked students three open questions: How does geography knowledge contribute to your life? What is the meaning of geography? What do you think is the purpose of teaching geography? Based on the answers, they created a questionnaire survey for 280 students in the second phase of the research. The questionnaire contained 17 items classified into three dimensions: basic knowledge, basic geographical knowledge, and values.

\subsection{The image of geography}

Due to the differences between individual studies, I first evaluate how the image of geography is perceived by students, and then describe the factors that affect the image of geography.

\subsubsection{Geography in comparison with other school subjects}

The oldest study, done in the United States, looked at students' attitude to geography. Most secondary school students ranked geography as the 4 th or 5 th most popular subject in the social sciences (geography, history, economics, psychology and sociology, government). A quarter of students even identified it as the least favorite subject, and less than a tenth of students considered it the most popular subject (McTeer 1979). 
Nearly the same results were reported in a study conducted in Texas. A survey was repeatedly conducted among lower secondary students. The classes in which key geographical knowledge is developed were selected, so the students were expected to be able to think at the community, regional, and global levels. In 1983 and 1993, the students were asked to rank art, music, physical education, mathematics, geography, reading, and science according to their preference. Geography came out as the least popular in both years, although in 1993 the popularity rose from the original $8 \%$ to $14 \%$. Geography was more popular only within the social sciences (anthropology, geography, economics, history, sociology, government), where it appeared as an average subject (Sack, Petersen 1998).

Longitudinal research was conducted in Poland by Mularczyk (2011), who examined students' attitudes towards geography in 1989, 2002, and 2009 using a questionnaire survey. The ranking of geography changed over this period, likely in response to changes in the curriculum. In 1989, students considered geography the most favorite subject, but in 2002, geography was one of the least favorite subjects (10th place). In a follow-up study, Hibszer (2011) confirmed that geography was not a popular subject in Poland. The most popular subjects were mathematics and Polish. The most likely deciding factor was that both of these subjects had the greatest number of hours per subject, and students most often took final exams in these subjects. If we compare only the subjects within the natural sciences, geography ranked second.

\subsubsection{Attitudes of students toward geography}

Czech students had a neutral to slightly positive attitude toward geography (Kubiatko, Janko, Mrazkova 2012). Students commented on four specific dimensions: geography as a subject; geography and the natural environment; the importance of geography; and the relevance of geography in everyday life. The average attitude score was 3.36 on the 5-point Likert scale, which the authors explain by continuing teacher-centered teaching or teaching that emphasizes factual knowledge. Younger lower secondary students repeatedly had the highest scores, mainly because geography was a new subject for them, and they still had the motivation to learn new things. At higher grade levels, Czech students gradually lost their positive attitude toward geography. This may be because the curriculum became less interesting from the students' point of view (Kubiatko, Janko, Mrazkova 2012).

In a similar study conducted in Slovakia, students rated geography 3.41 on a 5-point Likert scale. Specifically, $10.7 \%$ of students had a neutral attitude toward geography, $19.4 \%$ had a negative attitude, and $69.9 \%$, positive. Attitudes changed from grade to grade, and the main factor was the topics taught in each grade. In the 6 th and 7th grades, more complex topics from regional geography were covered, 
while in the 9th grade, geography class deals with Slovakia, which the students described as simple, therefore the attitude downfalls (Karolčík et al. 2019).

The attitudes of Polish students were also neutral; although the students quite enjoyed the subject, they were not interested in studying it in more depth. Students also perceived geography more positively when learning topics applicable in everyday life (Mularczyk 2011). Tracz (2011) also obtained similar results from a questionnaire survey. She found that $88.3 \%$ of the students surveyed described geography as an interesting subject; however, only $4 \%$ of students would have chosen it for further study. Despite answering negatively when asked whether they would study geography further, $65 \%$ stated that they would choose it as a supplementary subject for their secondary final examination (Tracz 2011). Another Polish survey found that $25 \%$ of the interviewed students were interested in geography, $39 \%$ enjoyed geography, and $22 \%$ found geography challenging (Hibszer 2011).

Tomal (2010) examined the relationship of students to geography in secondary and vocational secondary schools in Turkey. Students ranked geography as the 4th most popular subject and had a generally positive attitude toward geography. $75.2 \%$ of students stated that they liked geography. Students explained their positive answers by noting the importance of geography for everyday life, saying that they can apply a lot of the information to their surroundings or the environment (Tomal 2010). In later research in secondary schools, Aydin and Tülümen (2018) and Sözen (2019) obtained similar results.

\subsubsection{The usefulness of geography}

In the UK, $62.3 \%$ of students thought they were learning useful things when studying geography (Adey, Biddulph 2001). Perhaps the most positive impression of geography came from semi-structured interviews in Ghana, where more than three-quarters of the students liked geography. Geography is a unique discipline, which offers holistic knowledge, skills, and understanding of the processes that take place in it. In Africa, it is very important for students to be able to apply what they are learning in everyday life. Using geography, they can learn about weather and climatic conditions-information that is essential for planning human activities at different scales. It is also crucial for students to know whether this subject would be helpful in their future studies and whether it can help them to find a job later (Opoku, Serbeh, Amoah 2020).

Students in Hong Kong had a similar perception of geography. Older students appreciated the usefulness of geography in everyday life and the way it helped them understand the spatial connection between objects. Younger students thought of geography more as a study of places. It was found that age plays a role in how students understand the subject, but that the attitude toward the subject 
does not change much. Interviews showed that 10 out of 12 students had a markedly positive attitude to geography (Lam, Lai 2003).

\subsubsection{Students' perception of geography}

Qualitative research on the perception of geography seeks to learn what geography is according to students, what it deals with, and what makes it interesting for students. Students in Oman had a relatively positive perception of geography, and, in most cases, included it among their favorite subjects. Students were also able to say what they thought the subject of geography was, and always included more than two aspects of geography in their definitions (Al-Nofli 2010). In contrast, Hopwood, Courtley-Green, and Chambers (2005) found that students had trouble identifying what exactly geography was, but generally perceived it positively. Hopwood (2009) found that students' views on geography and their preferences for geographical topics could vary widely. However, a positive attitude toward geography prevailed among the participating students. They considered geography an interesting subject with many facts to learn, and, at the same time, one that could teach them to think (Hopwood 2009).

Harrison and Norman (2004) asked students to provide keywords and experiences related to geography. Their answers were divided into four dimensions related to looking at geography: the level of interest in geography; things that students enjoyed, things they did not enjoy in geography lessons; and the experience they had gained through attending the classes. The students' answers varied greatly. The first group of students did not answer. The second group could not remember anything they had learned in geography. Surprisingly, these groups amounted to $43 \%$ of participating students. However, some of the students were able to apply what they had learned in geography to everyday experience and could describe the lessons in detail (Harrison, Norman 2004).

\subsection{Factors Influencing the Image of Geography}

\subsubsection{The teacher: Personality and expertise}

Possibly the most decisive factor in whether a student likes geography and becomes interested in it is the teacher and his/her approach to teaching (Karolčík et al. 2019; Adey, Biddulph 2001; Hopwood 2014; Sözen 2019). McTeer (1979) also highlighted the teacher's ability to engage students. If the teacher only prepares one-sided, boring lessons, geography is not popular; on the other hand, if the teacher is helpful and active, he/she enjoys great popularity and respect (Tomal 2010, Al-Nofli 2010). The second decisive factor for the students is whether the 
teacher himself/herself enjoys the curriculum (Burnett, Crowe 2016). The popularity of geography is often lower if teachers have been teaching for only a short time and lack sufficient experience or a teaching specialization (Sack, Petersen 1998). Students even realize that the lessons would be much better and more interesting if the teacher had specialized in the relevant subject (Hibszer 2011). The curriculum and its composition are also factors that can support or undermine the teacher's efforts (Lam, Lai 2003).

\subsubsection{The influence of close relatives and friends}

In addition to teachers, parents are an important factor (Hopwood 2014, Karolčík et al. 2019; Opoku, Serbeh, Amoah 2020). Parents can act as motivators, deciding whether a student would continue to study geography in the future (Adey, Biddulph 2001). Kitchen (2013) also reported the strong influence of factors such as friends, television, and travel, as each student perceives geography very individually.

\subsubsection{Teaching methods}

Teaching methods are the second most frequently mentioned factor influencing the image of geography from the perspective of students. The use of active methods contributes to a positive attitude among students (Sack, Petersen 1998; Hopwood, Courtley-Green, Chambers 2005). Students appreciate opportunities to solve problems, work with a map, present projects, create posters, watch instructional videos, or go out into the field, where geographical phenomena can be experienced and remembered better (Biddulph, Adey 2001, 2004; Harrison, Norman 2004; Opoku, Serbeh, Amoah 2020). Students also appreciate the use of technology in teaching geography (Burnett, Crowe 2016; Aydin, Tülümen 2018), especially when working with digital maps (Hibszer 2011). By contrast, they perceive as negative working with textbooks and written texts. They have problem with the high cognitive complexity of teaching geography associated with a high degree of independent work and problem-solving (Adey, Biddulph 2001; Biddulph, Adey 2003). Students lose interest in geography if only passive effort is required, such as listening to an explanation, copying from the board, learning material from a textbook (Al-Nofli 2010, Sözen 2019). Some students are also not in favor of participating in group projects, analyzing the weather, or taking a test (Norman 2004). As a general rule, if a type of teaching lasts too long, students lose interest (Adey, Biddulph 2001). Working with a map and creating maps have also been listed by some students as unpopular teaching activities (Harrison, Norman 2004). 


\subsubsection{Memorizing facts}

Clearly detrimental to the image of geography is the teaching strategy based on the memorization of things and places (McTeer 1979, Karolčík et al. 2019). This is one of the reasons why geography is not perceived as a simple subject: students need to be able to recall a large amount of information to succeed (Mularczyk 2011, Hibszer 2011). Students welcome more clear connections between facts and the use of visual aids to help them remember (Jan Bent, Bakx, den Brok 2013). Geography has a wide scope, and it is often difficult for students to understand all the processes; they cannot learn everything in depth, which becomes stressful if they cannot achieve good grades. These feelings can even result in anxiety (Opoku, Serbeh, Amoah 2020).

\subsubsection{The geography curriculum, topics, and themes}

Geographical topics are another key factor shaping the image of geography (Karolčík et al. 2019). The most favorite topics intertwine within the studies. Students most often mentioned foreign countries, cultures, and places; the weather; human and physical geography; the environment; animals and populations; and maps (Kitchen 2013; Norman 2004; Hopwood, Courtley-Green, Chambers 2005; Al-Nofli 2010; Burnett, Crowe 2016; Senyurt 2014); natural hazards and disasters (Norman 2004; Hopwood, Courtley-Green, Chambers 2005; Al-Nofli 2010); and environmental issues (Kitchen 2013). However, some research shows that students have a problem not with the topic, but with the fact that it was not taught in an interesting way or that they did not understand it (Biddulph, Adey 2004; Hibszer 2011). The second problem is that the topics are often repeated in the curriculum, and the geographical curriculum tends to be less interesting for older students (Al-Nofli 2010). The last general remark, which does not relate directly to the content of the subject, is that students want greater coherence of topics and placement in a broader context (Jan Bent, Bakx, den Brok 2014).

We can identify the preferred topics for students from different regions. Senyurt (2014) found that popular topics for Turkish students were the relief, the region of Turkey, and working with maps. Turkish students clearly preferred the field of physical geography. Al-Nofli (2010) also observed a preference for physical-geographical topics in Oman. Other regional specificities were covered in an Israeli study, which identified the influence of geographical factors on population, economy, politics, cross-border relations, and border formation as the most interesting topics. On the other hand, Israeli students were less interested in learning about other cultures. The sample examined included both Jewish and Arab students, and there were obvious differences between them. While Arab students prioritized environmental issues, Jewish students preferred the study of political conflicts or the issue of demarcation (Bar-Gal, Sofer 2010). 


\section{Discussion}

\subsection{The Concept of the Image of Geography}

The most commonly used construct for examining the image of geography from the students' point of view was perception, which appeared in half of the studies. Perception is the process of receiving the simplest isolated elements (Adey, Biddulph 2001). It reflects what the individual feels at a given moment and how the environment affects him/her. It also reveals the subjective reflection of objective reality in our consciousness through receptors. Therefore, it is a research construct that has one dimension and directly reflects the subjective feelings of the individual, making it a suitable tool.

The second most frequently used research construct was attitude (Eagly, Chaiken 1993), divided into three dimensions (cognitive, conative, and affective), which can be clearly distinguished from each other and were usually taken into account in the questionnaire surveys. Conception (Walter 2008) and interest (Schiefele 1991) were used in two studies. An idea is actually a type of image that consciousness subjectively creates and presents to the outside through themes. Ideas can have a fairly broad scope, as can interest. Interest is very closely connected with motivation, which is the inner strength of the individual and is responsible for initiating efforts and directing behavior. Each student's interest in the subject or motivation to study the subject is based on different motives, and we certainly cannot simply say that individual has a positive or negative idea of geography. This construct allows us to examine only a part of the attitude, and we cannot capture the overall picture of how the student feels about the issue. Thus, the best constructs for investigating the image of geography are certainly attitude and perception.

\subsection{The methods}

The most common research tool for examining the image of geography was a questionnaire survey. From the point of view of the subsequent analysis, it proved to be more advantageous to focus on closed questions where students indicated their level of interest on a Likert scale. The most useful were 4- or 5-point Likert scales (Hubbard, Stoddard 1979; Tomal 2010; Kubiatko, Janko, Mrazkova 2012). In the Polish research, a scale of up to 18 points was used, which seemed confusing and misleading (Mularczyk 2011). The yes/no answer option was also used for closed questions (Adey, Biddulph 2001).

Questionnaires that asked students to rank subjects according to preference yielded some information but were less valuable for determining image (McTeer 
1979; Sack, Petersen 1998). The comparison with other subjects is difficult, and given a choice of, for example, physical education, art, or music, students will almost always prefer the easier and more interesting subjects to subjects where knowledge and demonstration of competencies are required. Research of this type is, therefore, rather relevant in the context of related subjects. in this case with other natural sciences or sociological subjects.

The second most common research tool was semi-structured interviews (Hopwood 2014; Lam, Lai 2003). In this case, the researcher has the opportunity to talk to the participating individuals repeatedly, so he/she can better understand their internal motives and deeper connections. I found semi-structured interviews an important supplement in the research on the image of geography. They are most useful if they supplement either a questionnaire survey or another form of preliminary research. Mixed design research by Harrison and Norman (2004) or Kitchen (2013) seems to be very complex and useful, using semi-structured interviews in the research, but the interviews were preceded by the creation of posters or answers to open-ended questions. In addition, the researchers had the opportunity to closely monitor a group of at least 60 students, so their conclusions are more generalizable.

\subsection{The findings}

Interest in geography is often conditioned by the topics discussed in geography lessons (Hemmer, Hemmer 2017). Students are often motivated by curiosity rather than by a desire for knowledge, so they prefer topics that are personally interesting and applicable to everyday life (Kidman 2018; Piróg, Hibszer 2020). For example, the applicability (of knowledge) in everyday life was probably a decisive factor in the case of Poland, where declining trends were observed in students' interest in the subject during the years 1990-2009. The studies also showed that the usefulness of geography was correlated with the respondents' age (Piróg, Hibszer 2020). The image of geography from the students' point of view is undoubtedly also influenced by other factors, such as teacher's attitude to geography and how he/she passes on geographical knowledge to students (Martin 2000; Kubiatko, Janko, Mrazkova 2012; Jan Bent, Bakx, den Brok 2014). The popularity of geography among students can be increased with innovative methods and forms of teaching, such as case studies, field teaching, and the use of modern technologies (Senyurt 2014; Miener 2016; Svobodová et al. 2019).

I obtained a wide range of results, as all studies asked different main research questions. Findings addressed what geographical topics students liked and did not like; what teaching methods they preferred; and why they enjoyed geography in the first place. Each study revealed the unique view of a group of students on 
geography, but also revealed the unique view of individuals from a particular country. I included publications from multiple continents, so the results are at least partially generalizable. There were regional differences in the perception of the image of geography from the perspective of students. Students from developed countries were most interested in social geography, with an emphasis on solving current environmental, interpersonal, and global problems. Interestingly, in developed countries, students were not interested in physical geography, because they did not seem to feel that they would use it much in later life (Kitchen 2013, Hopwood 2014). Conversely, students from developing countries (Senyurt 2014; Opoku, Serbeh, Amoah 2020) preferred physical geographical topics, which can be explained mainly by these students' stronger connection with nature, the countryside, and agriculture. Clearly, each country has its own contextual specifics and views geography from a unique cultural angle. A notable example is Israel (Bar-Gal, Sofer 2010), where students stated that the most important topics in geography were economics, politics, cross-border relations, and demarcation.

In developed countries, students were most concerned with the forms of teaching, the usefulness of geography in later life, as well as the role of the teacher in teaching. After parents, teachers had the most consistent effect on students, and can have the greatest impact on the relationship between students and geography (Burnett, Crowe 2016). The decisive factors were whether the teacher was qualified to teach geography; whether he/she enjoyed teaching the subject; and how long he/she had been teaching (McTeer 1979). In the Netherlands, for example, there is great pressure for in-service teachers to undergo training to ensure that they can prepare interesting geography lessons and thus reach more students (Jan Bent, Bakx, den Brok 2014).

In most of the studies, the students agreed on which methods of learning geography they did and did not enjoy. A comprehensive list of popular activities was presented by Norman (2004). Students preferred active methods where they could get involved, think about problems, create posters, participate in group work, create and work with maps, etc. On the other hand, they did not like to work with a textbook, copy from the board, perform independent activities, or passively listen to the teacher's explanation. In general, they did not want one-sided activities, preferring more variable teaching. These findings were confirmed in other studies, such as Kubiatko, Janko, and Mrazkova (2012) and Burnett and Crowe (2016).

\section{Conclusion}

This review includes an adequate sample of studies that provide a sufficient basis for a detailed analysis. It prepared the ground for designing my own research. The review also has its limitations. One of them is the definition of the term "image", 
which is very broad. Therefore, it was not possible to include and search all publications thanks to the chosen keywords. Snowball sampling had to be done in addition to the keyword search. Another limitation is the slightly variable focus of the selected studies. Although all the studies investigated aspects of the image, each reported a completely different spectrum of results. A further key limit seems to be the age differences between the groups of students researched. The younger students were able to express their perceptions only partially through key words and concepts, while the older students (from higher secondary schools) could provide more detailed commentary on their perceptions. Therefore, the image of geography seemed to change with the age of the students.

I have identified factors that influence the students' image of geography. The most important factors are the teacher's personality; the teacher's approach to teaching and teaching strategy; and the thematic focus of the curriculum and teaching. Other factors that are evident, and emerged from this review, consist of the different cultural customs and value orientations of different societies. The level of economic development, internal political situation, and geopolitical position are all factors that influence which topics students find attractive and useful. These factors also influence the preferences for teaching strategies.

In addition to the answers, this review also raises several other questions. We will try to answer them in follow-up research. The questions include the following: What is the image of geography in the Czechia? Will follow-up research confirm the factors that have already been identified, or will it reveal other factors? Does the image of geography depend on whether the students live in urban or rural areas?

Therefore, it is absolutely crucial that follow-up research take into account the existing knowledge. This information must also be considered when creating questionnaire surveys. The questionnaire survey proved to be the most frequently used and, for my research, the most useful method of data collection. As part of the piloting, or as a supplement to the survey itself, it is beneficial to include semistructured interviews to resolve any ambiguities that may have arisen. Given that geography itself is taught integrated starting at the primary school level, and that most students around the world encounter it properly between the ages of 11 and 15, it would be most strategic for future surveys to be conducted with older students (14-15 years). They can already express their own opinion based on their experience, but their perception can still be shaped in the future by introducing the right topics or new interesting knowledge. Based on the planned research and further investigation, it will be possible to devise additional steps to maintain the image of geography systematically and raise the prestige of geography as a subject. 


\section{References}

ADEY, K., BIDDULPH, M. (2001): The Influence of Pupil Perceptions on Subject Choice at 14+ in Geography and History. Educational Studies, 27, 4, 439-450.

AL-NOFLI, M.A. (2010): Students' perceptions about geography: A study of basic education school students in Oman. European Journal of Social Sciences, 16, 1, 11-20.

AYDIN, F., TÜLÜMEN, M. (2018): Examining the Anxiety and Attitudes of Secondary School Students towards Geography Lessons in terms of Some Variables. Review of International Geographical Education Online, 8, 3, 473-499.

BAR-GAL, B., SOFER, S. (2010): Israeli students' perceptions of geography instruction goals. International Research in Geographical and Environmental Education, 19, 2, 127-137.

BÉNEKER, T., PALINGS, H., KRAUSE, U. (2015): Teachers envisioning future geography education at their schools. International Research in Geographical and Environmental Education, $24,4,355-370$.

BERGER, P.L., LUCKMANN, T. (1991): The social construction of reality: A treatise in the sociology of knowledge (No. 10). Penguin UK.

BIDDULPH, M., ADEY, K. (2003): Perceptions v. reality: pupils' experiences of learning in history and geography at Key Stage 4. The Curriculum Journal, 14, 3, 291-303.

BIDDULPH, M., ADEY, K. (2004): Pupil perceptions of effective teaching and subject relevance in history and geography at Key Stage 3. Research in Education, 71, 1, 1-8.

BURNETT, A., CROWE, L. (2016): An evaluation of secondary school students' perceptions of geography at Key Stages 3 and 4. The Sheffield Hallam University Natural Environment Research Transactions, 2, 1, 53-79.

COLMAN, A.M. (2015): A dictionary of psychology. Oxford quick reference. Oxford: Oxford University Press.

DAWSON, J., HEBDEN, R. (1984): Beyond 1984: The image of geography. Area, 16, 3, 254-256.

EAGLY, A.H., CHAIKEN, S. (1993): The psychology of attitudes. Orlando (Harcourt Brace Jovanovich College Publishers).

GIBSON, C. (2007): Geography in higher education in Australia. Journal of Geography in Higher Education, 31, 1, 97-119.

HARRISON, L., NORMAN, M. (2004): Pupils Perceptions of Geography: KS2/3 transfer issues. Researching Primary Geography, 256-265.

HEMMER, I., HEMMER, M. (2017): Teachers' Interests in Geography Topics and Regions. How They Differ from Students' Interests? Empirical Findings. Review of International Geographical Education Online, 7, 1, 9-23.

HIBSZER, A. (2011): Perceiving Geography As A School Subject By Pupils Of Lower Secondary School (In The Cities Of Silesian Voivodeship). Prace i Studia Geograficzne, 48, 97-109.

HOPWOOD, N., COURTLEY-GREEN, C., CHAMBERS, T. (2005): Year 9 students' conceptions of geography. Teaching Geography, 30, 2, 91-93.

HOPWOOD, N. (2009): UK high school pupils' conceptions of geography: research findings and methodological implications. International Research in Geographical and Environmental Education, 18, 3, 185-197.

HOPWOOD, N. (2014): Geography in Secondary Schools: Researching pupils' classroom experiences. Bloomsbury Publishing.

HUBBARD, R., STODDARD, R.H. (1979): High school students' images of geography: An exploratory analysis. Journal of Geography, 78, 5, 188-194.

IMBER, J., TOFFLER B. (2000): Dictionary of Marketing Terms, 3. bs. 
JAN BENT, G., BAKX, A., DEN BROK, P. (2013): Pupils' Perceptions of Geography in Dutch Primary Schools: Goals, Outcomes, Classrooms Environment, and Teacher Knowledge and Performance. Journal of Geography, 113, 1, 20-34.

KAROLČÍK, Š., ČIPKOVÁ, E., JURČÍKOVÁ, S., MÁZOROVÁ, H. (2019): Attitudes of Pupils in Lower Secondary Education towards Geography Subject. Geographia Cassoviensis, 13, 1.

KIDMAN, G. (2018): School geography: what interests student, what interests teacher? International Research in Geographical and Environmental Education, 27, 4, 311-325.

KITCHEN, R. (2013): Student perceptions of geographical knowledge and the role of the teacher. Geography, 98, 3, 112-122.

KUBIATKO, M., JANKO, T., MRAZKOVA, K. (2012): Czech Student Attitudes towards Geography. Journal of Geography, 111, 2, 67-75.

LAM, C., LAI, E. (2003): 'What is Geography?' In the Eyes of Junior Secondary Students in Hong Kong. International Research in Geographical and Environmental Education, 12, 3, 199-218.

MILLS, C.W. (2000): The sociological imagination. Oxford University Press.

MIENER, K.P. (2016): Das Image des Unterrichtsfachs Geographie aus der Perspektive von Schülerinnen und Schülern. Eine empirische schulartenübergreifende Untersuchung in der Sekundarstufe I in Nordrhein-Westfalen. Geographiedidaktische Forschungen, 64.

MCTEER, H.J. (1979): High school students‘ attitudes toward geography. Journal of Geography, 78, 2, 55-56.

MULARCZYK, M. (2011): From Fascination to Indifference - Changes in Students' Attitudes Towards Geography as a School Subject in 1989-2009. Prace i Studia Geograficzne, 48, 87-95.

MURPHY, R. (2018): Rationality and nature: A sociological inquiry into a changing relationship. Routledge.

NEUENDORF, K.A. (2016): The content analysis guidebook. Thousand Oaks, Sage.

NORMAN, M. (2004): Year 9 students' perceptions of school geography. Teaching Geography, $29,11-15$.

OPOKU, F., SERBEH R., AMOAH, E.G. (2020). Geography education in perspective: an enquiry into Ghanaian senior high school students' positive and negative attitudes towards geography. International Research in Geographical and Environmental Education, 30, 1, 39-53.

PARKINSON, A. (2020): Why Study Geography? London: London Publishing Partnership.

PETTICREW, M., ROBERTS, H. (2008): Systematic reviews in the social sciences: A practical guide. John Wiley \& Sons.

PIRÓG, D., HIBSZER A. (2020): The situation of geography teachers on the labour market in Poland: overt and covert issues. European Journal of Geography, 11, 2, 65-87.

RALLIS, D.N., RALLIS, H. (1995): Changing the image of geography. The Social Studies, 86, 4, 167-168.

SACK, D., PETERSEN, J.F. (1998): Children's attitudes toward geography: a Texas case study. Journal of Geography, 97, 3, 123-131.

SCHIEFELE, U. (1991): Interest, learning, and motivation. Educational psychologist, 26, 3-4, 299-323.

SENYURT, S. (2014): Turkish primary students' perceptions of geography. Journal of Geography, $113,4,160-170$.

SNYDER, H. (2019): Literature review as a research methodology: An overview and guidelines. Journal of business research, 104, 333-339.

SÖZEN, E. (2019): High school students' views and attitudes towards geography courses in Turkey. Review of International Geographical Education Online, 9, 2, 458-478. 
SVOBODOVÁ, H., MÍSAŘOVÁ, D., DURNA, R., ČEŠKOVÁ, T., HOFMANN, E. (2019): Koncepce terénní výuky pro základní školy. Masaryk University Press, Brno.

TOMAL, N. (2010): High school students' attitudes towards geography and the questions that they wonder about it. Scientific Research and Essays, 5, 13, 1729-1733.

TRACZ, M. (2011): Interest in geography and its studies among students of post secondary school. Prace i Studia Geograficzne Uniwersytetu Warszawskiego, 38, 79-86.

VAN DER SCHEE, J. (2014): Looking for an international strategy for geography education. J-Reading-Journal of Research and Didactics in Geography, 1.

WALTER, E. (2008): Cambridge advanced learner's dictionary. Cambridge University Press.

\section{ACKNOWLEDGMENTS}

Funding for this research was provided by the Masaryk University, Project MUNI/A/1337/2019, "Př́stupy a metody v edukačním procesu v geografickém vzdělávání".

\section{ORCID}

VERONIKA KORVASOVÁ

https://orcid.org/0000-0002-7049-7062 